\title{
Desulfobacca acetoxidans gen. nov., sp. nov., a novel acetate-degrading sulfate reducer isolated from sulfidogenic granular sludge
}

\author{
Stefanie J. W. H. Oude Elferink, † W. M. Akkermans-van Vliet, \\ Jaap J. Bogte and Alfons J. M. Stams
}

Author for correspondence: Stefanie J. W. H. Oude Elferink. Tel: +31 320237359 . Fax: +31 320237320 . e-mail: s.j.w.h.oudeelferink@id.dlo.nl

Department of

Microbiology, Wageningen

Agricultural University,

H.v. Suchtelenweg 4,

NL-6703 CT Wageningen,

The Netherlands

\begin{abstract}
A mesophilic sulfate reducer, strain ASRB2 ${ }^{\top}$, was isolated with acetate as sole carbon and energy source from granular sludge of a laboratory-scale upflow anaerobic sludge bed reactor fed with acetate and sulfate. The bacterium was oval-shaped, 1.3 $\times 1.9-2.2 \mu \mathrm{m}$, non-motile and Gram-negative. Optimum growth with acetate occurred around $37^{\circ} \mathrm{C}$ in freshwater medium (doubling time: 1.7-2.2 d). Enzyme studies indicated that acetate was oxidized via the carbon monoxide dehydrogenase pathway. Growth was not supported by other organic acids, such as propionate, butyrate or lactate, alcohols such as ethanol or propanol, and hydrogen or formate. Sulfite and thiosulfate were also used as electron acceptors, but sulfur and nitrate were not reduced. Phylogenetically, strain ASRB2 ${ }^{\top}$ clustered with the delta subclass of the Proteobacteria. Its closest relatives were Desulfosarcina variabilis, Desulfacinum infernum and Syntrophus buswellii. Strain ASRB2 ${ }^{\top}$ is described as the type strain of Desulfobacca acetoxidans gen. nov., sp. nov.
\end{abstract}

Keywords: Desulfobacca acetoxidans gen. nov., sp. nov., acetate, sulfate-reducing bacteria

\section{INTRODUCTION}

Sulfate-reducing bacteria play an important role in the degradation of organic matter in anaerobic bioreactors treating sulfate-rich wastewaters, such as those from paper mills, tanneries or food oil industry (Oude Elferink et al., 1994; Colleran et al., 1995). If sufficient sulfate is available, sulfate reducers can easily outcompete hydrogenotrophic methanogens and syntrophic consortia for substrates like hydrogen and propionate (Oude Elferink et al., 1994; Colleran et al., 1995; Visser, 1995). However, the outcome of the competition for acetate between sulfate reducers and methanogens in anaerobic wastewater treatment systems is less clear. In some studies with freshwater or

\footnotetext{
†Present address: DLO-Institute for Animal Science and Health (ID-DLO), Department of Ruminant Nutrition, PO Box 65, 8200 AB Lelystad, The Netherlands.

Abbreviations: $C O D$, chemical oxygen demand; UASB, upflow anaerobic sludge bed.

The GenBank accession number for the 16S rRNA gene sequence of strain $\mathrm{ASRB2}^{\mathrm{T}}$ is AF002671.
}

low-salt systems, acetate conversion via methanogenesis was predominant, even at an excess of sulfate (McCartney \& Oleszkiewicz, 1991; Isa et al., 1986; Visser et al., 1993a). Other studies report the predominance of acetate degradation via sulfate reduction (Alphenaar et al., 1993; Visser et al., 1993b; Harada et al., 1994). Factors which could affect the outcome of the competition between methanogens and sulfate reducers are, for example, the kinetic properties of the bacteria involved, the $\mathrm{pH}$ and temperature of the reactor, and the chemical oxygen demand (COD)/ sulfate ratio of the wastewater (Oude Elferink et al., 1994; Colleran et al., 1995; Visser, 1995). In wastewater with a COD/sulfate ratio below $0.67\left(\mathrm{~g} \mathrm{~g}^{-1}\right)$ there will be excess of sulfate allowing the degradation of all organic material via sulfate reduction.

Acetate is one of the major intermediates in the breakdown of organic matter in anaerobic bioreactors (Gujer \& Zehnder, 1983; Smith \& Mah, 1966). Therefore, it is important to know which sulfate reducers can compete with the acetoclastic methanogens present in the sludge. Although many mesophilic 
sulfate reducers can grow with acetate as sole electron donor and carbon source (Widdel, 1992; Widdel \& Bak, 1992), only a few show good growth with acetate under freshwater conditions. Among them are the Gram-positive Desulfotomaculum acetoxidans (Widdel \& Pfennig, 1981), the Gram-negative Desulfobacter strain AcKo (Widdel, 1987), and the Gram-negative Desulforhabdus amnigenus, which was recently isolated from granular sludge of an upflow anaerobic sludge bed (UASB) reactor treating papermill wastewater (Oude Elferink et al., 1995). In this paper we describe the isolation and characterization of a sulfate reducer from granular sludge of a laboratory-scale UASB reactor fed with acetate and an excess of sulfate. In this reactor sulfate reduction had completely superseded methanogenesis after 1 year of reactor operation.

\section{METHODS}

Origin of strain ASRB2 ${ }^{\top}$. The sulfate-reducing bacterium, strain ASRB2 ${ }^{\mathrm{T}}$, was isolated from the granular sludge of a pilot-scale UASB reactor (1.71) fed with acetate and an excess of sulfate. Initially, the reactor was seeded with sludge from a $101 \mathrm{UASB}$ reactor that had been fed with acetate and sulfate for more than 2 years. Detailed characteristics of this seed-sludge have been described elsewhere (Visser, 1985). The reactor influent had a COD/sulfate ratio of $0.6\left(\mathrm{~g} \mathrm{~g}^{-1}\right)$ and was treated at a temperature of $30^{\circ} \mathrm{C}$. Sludge samples were taken after 6 months and 1 year of reactor operation. During this period acetate degradation via sulfate reduction increased from approximately 80 to $100 \%$, while degradation via methanogenesis decreased from 20 to $0 \%$.

Media and cultivation. Unless stated otherwise, bacteria were cultured at $37^{\circ} \mathrm{C}$ in $120 \mathrm{ml}$ serum vials containing $50 \mathrm{ml}$ of a bicarbonate-buffered medium, and a gas phase of $172 \cdot 2 \mathrm{kPa} \mathrm{N} / \mathrm{CO}_{2}(80: 20, \mathrm{v} / \mathrm{v})$ as described previously (Oude Elferink et al., 1995). The inoculum size was $1 \%$.

Isolation. Granular sludge samples $(10 \mathrm{ml})$, taken from the reactor after 6 months and after 1 year of operation, were 10 fold diluted and disintegrated immediately after sampling as described previously (Oude Elferink et al., 1995). This crushed granular sludge was used to make 10-fold serial dilutions in liquid media containing acetate and sulfate (20 mM each). For each dilution, $5 \mathrm{ml}$ inoculum was added to $45 \mathrm{ml}$ medium. The cultures were incubated at $30^{\circ} \mathrm{C}$, and the highest dilutions which showed growth were used for further isolation. Pure cultures were obtained by repeated application of the agar roll-tube dilution method as described by Hungate (1969). Purity of the isolates was checked by microscopic observations and by testing anaerobic growth on pyruvate and glucose with $0 \cdot 1 \%$ yeast extract (BBL, Becton Dickinson), and on Wilkins-Chalgren anaerobe broth (Oxoid).

Growth experiments. Utilization of carbon sources, electron donors, and electron acceptors were tested in basal bicarbonate-buffered medium as described before (Oude Elferink et al., 1995). In most cases growth was followed by measuring substrate utilization and sulfide production, and by visual examination of culture turbidity. All tests were performed at a predetermined temperature, $\mathrm{pH}$ and salinity, allowing optimal growth of the isolate (Oude Elferink et al., 1995).

Analysis of cell compounds. Desulfoviridin was detected according to the methods of Postgate (1959). Cytochromes were identified in cell extracts by recording reduced-minusoxidized difference spectra with a Beckman DU7500 spectrophotometer, and on SDS-PAGE gel according to the methods of Thomas et al. (1976). The G+C content of the DNA was determined by HPLC at the Deutsche Sammlung von Mikroorganismen und Zellkulturen (DSMZ, Braunschweig, Germany). Gram staining was done according to standard procedures (Doetsch, 1981). The presence of gas vacuoles was determined by microscopic examination of late-exponential phase cultures before and after a pressureshock treatment in a hypodermic syringe.

Chemical analysis and enzyme measurements. Substrates were measured by HPLC or GC as described by Oude Elferink et al. (1995). Sulfide was determined as described by Trüper \& Schlegel (1964), and protein was measured according to the method of Bradford (1976). The enzyme activities of carbon monoxide dehydrogenase, formate dehydrogenase and 2-oxoglutarate dehydrogenase activities were assayed according to Schauder et al. (1986), using anoxically prepared cell extracts (Jetten et al., 1990) of cells grown with acetate and sulfate and harvested in the lateexponential phase.

Sequence analysis and phylogenetic tree. The $16 \mathrm{~S}$ rRNA gene of strain ASRB2 ${ }^{\mathrm{T}}$ was selectively amplified as described previously (Harmsen et al., 1993), using a set of universal $16 \mathrm{~S}$ rRNA-based primers: forward primer [5' CACGGATCCAGAGTTTGAT(C/T)-(A/C)TGGCTCAG] corresponded to positions 8-27 of Escherichia coli 16S rRNA, and the reverse primer ( $5^{\prime}$ GTGCTGCAGGGTTACCTTGTTACGACT) corresponded to positions 1493 to 1510. Amplification products were cloned in the $\mathrm{pGEM}^{\mathrm{R}}-\mathrm{T}$ vector according to the manufacturers protocol (pGEM ${ }^{\mathrm{R}}-\mathrm{T}$ Vector Systems, Promega). Plasmids of the clones were isolated by Wizard Plus Minipreps DNA Purification System according to the manufacturer's instruction (Promega). The inserts were amplified using primerset 77 (5' AATACGACTCACTATAG) and Sp6 (5' ATTTAGGTGACACTATA). The PCR products were sequenced with a LICOR $4000 \mathrm{~L}$ sequencer, by using Thermo Sequenase fluorescent-labelled primer cycle sequencing with 7-deaza-dGTP according to the manufacturer's protocols (Amersham). The total $16 \mathrm{~S}$ rRNA gene sequence was determined and aligned to those of other bacterial sequences, taking into account sequence similarity and higher order structure, using the alignment tool of the ARB program package (Ludwig \& Strunk, 1996).

\section{RESULTS}

\section{Isolation and morphological characterization}

Strain ASRB2 ${ }^{\mathrm{T}}$ was the dominant acetoclastic sulfate reducer in sludge samples taken from the reactor after 6 months and 1 year of operation. The highest sludge dilutions $\left(1 \times 10^{8}\right.$ and $\left.1 \times 10^{9}\right)$ showing growth on acetate and sulfate were used for the isolation of strain $A S R B 2^{T}$ by a repeated application of the agar rolltube dilution method. In agar the strain grew in greyish colonies with an irregular shape. Cells of the isolate were non-motile oval to rod-shaped $(1.3 \mu \mathrm{m}$ wide $\times$ $1 \cdot 9-2 \cdot 2 \mu \mathrm{m}$ long), and appeared singly or in pairs (Fig. 1). Cells stained Gram-negative. Spores were never observed. Late-exponential phase or stationary phase cells often contained light-reflecting inclusions that 


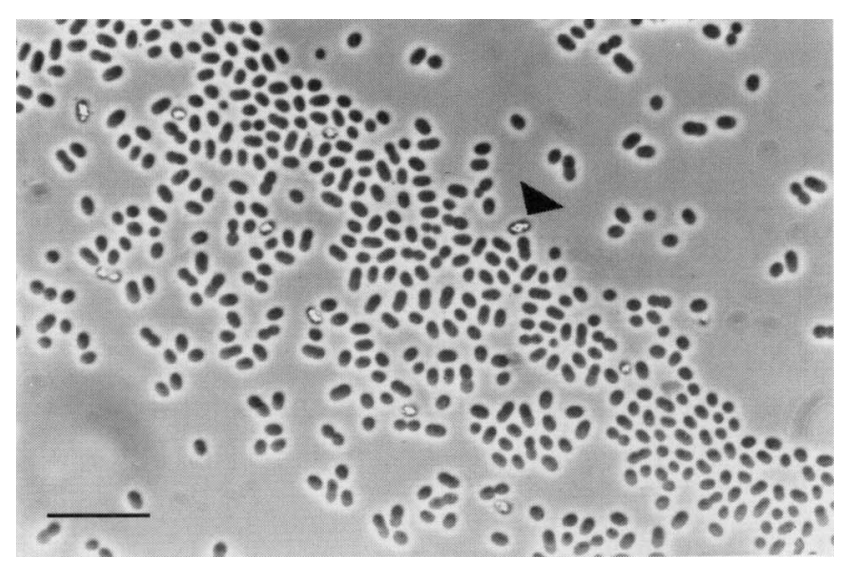

Fig. 1. Phase-contrast photomicrograph of strain $A S R B 2^{\top}$. Arrowhead indicates a cell with a gas vacuole. Bar, $10 \mu \mathrm{m}$.

could be destroyed by pressure-shock treatment, indicating that the inclusions were gas vacuoles.

\section{Growth conditions and substrate utilization}

The optimum growth temperature for strain ASRB2 ${ }^{\mathrm{T}}$ on acetate and sulfate was between 36 and $40^{\circ} \mathrm{C}$. Little growth was observed below $27^{\circ} \mathrm{C}$ or above $47^{\circ} \mathrm{C}$. The optimum $\mathrm{pH}$ for growth was $7 \cdot 1-7 \cdot 5$; growth was possible between $\mathrm{pH} 6.5$ and $8 \cdot 3$. The shortest doubling time on acetate was $1 \cdot 7-2 \cdot 2 \mathrm{~d}$. Growth in brackish medium was slow (the doubling time increased 4-8fold), and no growth was observed in marine medium. When vitamins were omitted from the media, cultures could be transferred ( $1 \%$ inoculum size) at least four times without any growth retardation.

In the presence of acetate, strain $\mathrm{ASRB} 2^{\mathrm{T}}$ could use $(\mathrm{mM})$ sulfate (20), thiosulfate (20) or sulfite (5) as electron acceptor; sulfur (5), nitrate (5) and fumarate (10) were not used. Strain ASRB2 ${ }^{\mathrm{T}}$ was specialized in the degradation of acetate, and complete oxidation of $10 \mathrm{mM}$ acetate led to a concomitant formation of $9.6 \mathrm{mM}$ sulfide. The threshold for acetate was below $15 \mu \mathrm{M}$, the detection threshold of our gas chromatograph. Compounds tested but not utilized as electron donors by strain $\mathrm{ASRB} 2^{\mathrm{T}}$ were $(\mathrm{mM})$ : propionate (20), butyrate (20), lactate (20), $\mathrm{H}_{2} / \mathrm{CO}_{2}(80: 20, \mathrm{v} / \mathrm{v})$ with or without acetate (2), formate (10) with or without acetate (2), ethanol (20), propanol (10), butanol (10), pyruvate (20), fumarate (20), glucose $(20)$, crotonate $(5)$, benzoate $(1)$, phenol $(0 \cdot 5)$, aspartate (5) and glutamate (5).

The pathway of acetate oxidation was studied by enzyme measurements of key enzymes in cell-free extracts. The specific activities of carbon monoxide

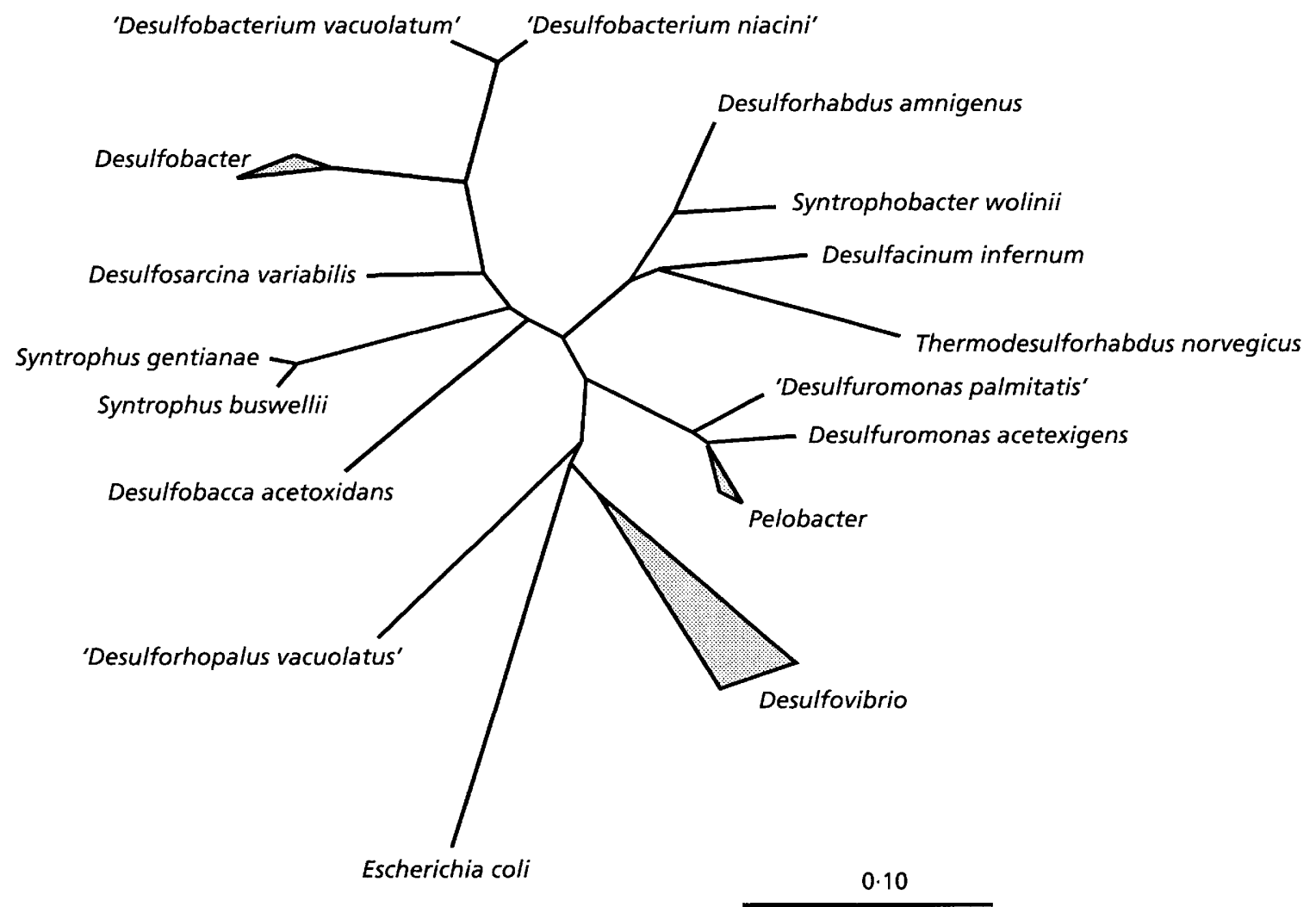

Fig. 2. Distance matrix tree reflecting the phylogenetic relationships of Desulfobacca acetoxidans strain ASRB2 $^{\top}$ with other sulfate reducers and relatives belonging to the delta subclass of the Proteobacteria. Bar, $0 \cdot 10 K_{\text {nuc }}$. 
dehydrogenase and formate dehydrogenase were 0.63 and $0.84 \mathrm{~mol} \mathrm{~min}^{-1}(\mathrm{mg} \text { protein })^{-1}$, respectively. 2Oxoglutarate dehydrogenase activity could not be detected.

\section{Pigments and other cell compounds}

Dithionite-reduced versus air-oxidized spectra of cell extracts of ASRB2 ${ }^{\mathrm{T}}$ revealed absorption maxima at 422,527 and $557 \mathrm{~nm}$, indicating the presence of c-type cytochromes (Mahler \& Cordes, 1969). The presence of $c$-type cytochromes was confirmed with the staining procedure on SDS gel (Thomas et al., 1976) (results not shown). Desulfoviridin could not be detected. The $\mathrm{G}+\mathrm{C}$ content of the DNA was $51 \cdot 1 \pm 0 \cdot 2 \mathrm{~mol} \%$.

\section{Phylogenetic analysis}

The phylogenetic relationships of strain ASRB2 ${ }^{\mathrm{T}}$ derived from 16S rRNA sequence analysis are depicted in Fig. 2. The 16S rRNA sequence shows that strain ASRB $2^{\mathrm{T}}$ is a member of the delta subclass of the Proteobacteria. A 16S rRNA sequence highly similar to that of ASRB2 ${ }^{\mathrm{T}}$ was not available in the database. Desulfosarcina variabilis, Desulfacinum infernum and Syntrophus buswellii were the closest relatives of $\mathrm{ASRB}^{\mathrm{T}}$; the level of sequence similarity was 86.9 , 85.6 and $85.5 \%$, respectively. The acetate-degrading sulfate reducer Desulforhabdus amnigenus was only moderately related to strain ASRB2 ${ }^{\mathrm{T}}$ (sequence similarity $85 \cdot 1 \%$ ).

\section{DISCUSSION}

\section{Physiology, ecology and taxonomy of strain ASRB2 ${ }^{\top}$}

Strain ASRB2 ${ }^{\mathrm{T}}$ was isolated from granular sludge of a laboratory-scale UASB reactor fed with acetate and an excess of sulfate. Cells resembling those of strain ASRB2 ${ }^{\mathrm{T}}$ were isolated from the sludge before and after sulfate reduction had superseded methanogenesis, by using the highest positive dilutions of two serial dilution ranges on acetate and sulfate. This strongly indicates that strain ASRB2 ${ }^{\mathrm{T}}$ is the most abundant acetate-degrading sulfate reducer in this sludge and is able to outcompete acetate-degrading methanogens. The only two genera of acetate-degrading methanogenic archaea known are Methanosarcina and Methanosaeta ('Methanothrix') (Whitman et al., 1992). Methanosaeta species generally are the most important methanogenic acetate degraders in anaerobic bioreactors, because of their high affinity and low threshold $(7-69 \mu \mathrm{M})$ for acetate (Oude Elferink et al., 1994; Jetten et al., 1992). The threshold of strain ASRB2 $2^{\mathrm{T}}(<15 \mu \mathrm{M})$ is in the same range as that of Methanosaeta sp. However, strain ASRB2 ${ }^{\mathrm{T}}$ has a higher specific growth rate $\left(\mu_{\max }=0.32-0.41 \mathrm{~d}^{-1}\right)$ than Methanosaeta sp. $\left(\mu_{\max }=0 \cdot 08-0 \cdot 29 \mathrm{~d}^{-1}\right)$. This could be one of the reasons why strain ASRB2 $2^{\mathrm{T}}$ is able to outcompete the acetate-degrading methanogens in the reactor. Strain ASRB2 ${ }^{\mathrm{T}}$ seems to be specialized in acetate consumption, this in contrast to the nutritionally versatile acetate-degrading Desulforhabdus amnigenus, which was recently isolated from a pilotscale UASB reactor treating papermill wastewater using the same isolation procedures as described for strain ASRB2 ${ }^{\mathrm{T}}$ (Oude Elferink et al., 1995). Apparently, the acetate-degrading sulfate-reducing population in the laboratory-scale reactor differs significantly from the population in the pilot-scale reactor. This is probably due to the different conditions in the pilot-scale reactor, such as the limiting sulfate concentration $\left(\mathrm{COD} /\right.$ sulfate $\left.=1 \cdot 1 \mathrm{~g} \mathrm{~g}^{-1}\right)$ and the more complex wastewater. The nutritional specialization of strain ASRB2 ${ }^{\mathrm{T}}$ is comparable to that of Desulfobacter sp. (Widdel, 1987), although some Desulfobacter species can use hydrogen and ethanol as well. However, the mean specific growth rate of Desulfobacter $\mathrm{sp}$. $\left(\mu_{\max }=0.8-1 \cdot 1 \mathrm{~d}^{-1}\right)$ (Oude Elferink et al., 1994) is approximately twice as high as that of strain ASRB $2^{\mathrm{T}}$. The oxidation of acetate in Desulfobacter sp. and in strain ASRB2 ${ }^{\mathrm{T}}$ occurs via different pathways. Desulfobacter $\mathrm{sp}$. use the citric acid cycle (Widdel, 1987), while strain ASRB2 ${ }^{\mathrm{T}}$ degrades acetate via the CO-dehydrogenase pathway. This is indicated by the high activity in cell-free extracts of strain ASRB2 ${ }^{\mathrm{T}}$, of carbon monoxide dehydrogenase and formate dehydrogenase, two key enzymes of the CO-dehydrogenase pathway, together with the absence of 2-oxoglutarate dehydrogenase activity, a key enzyme of the citric acid cycle (Schauder et al., 1986).

Phylogenetically, strain ASRB2 ${ }^{\mathrm{T}}$ clusters with the delta subclass of the Proteobacteria. Desulfobacter sp. is only distantly related to strain ASRB2 ${ }^{\mathrm{T}}$. The closest relatives are Desulfosarcina variabilis $(86.9 \%$ similarity), Desulfacinum infernum ( $85.6 \%$ similarity) and Syntrophus buswellii ( $85.5 \%$ similarity).

Physiologically and phylogenetically strain ASRB2 ${ }^{\mathrm{T}}$ differs significantly from the syntrophically benzoateoxidizing S. buswellii (Wallrabenstein et al., 1995), the thermophilic Desulfacinum infernum (Rees et al., 1995), and the nutritionally versatile Desulfosarcina variabilis (Widdel \& Bak, 1992). Therefore, we propose that strain ASRB2 ${ }^{\mathrm{T}}$ represents a new species of a new genus. We propose the name Desulfobacca acetoxidans gen. nov., sp. nov. for this organism.

\section{Description of Desulfobacca gen. nov.}

Desulfobacca (de.sul.fo.bac'ca. L. pref. de from; L. n. sulfur sulfur; M.L. pref. Desulfo- desulfuricating, used to characterize a dissimilatory sulfate-reducing prokaryote; L. fem. n. baca or bacca berry, especially olive; M.L. fem. n. Desulfobacca a sulfate-reducing, olive-shaped bacterium).

Non-motile, oval to rod-shaped cells. Sulfate or other inorganic sulfur compounds, but not elemental sulfur, serve as terminal electron acceptor and are reduced to $\mathrm{H}_{2} \mathrm{~S}$. Acetate is the common electron donor and carbon 
source, and is completely oxidized to $\mathrm{CO}_{2}$ via the $\mathrm{CO}$ dehydrogenase pathway. Desulfobacca belongs to the delta subclass of the Proteobacteria; the closest relatives are Desulfosarcina variabilis, Desulfacinum infernum and Syntrophus buswellii.

\section{Description of Desulfobacca acetoxidans sp. nov.}

Desulfobacca acetoxidans (a.cet.o'xi.dans. L. n. acetum vinegar; M.L. part. pres. oxidans oxidizing, M.L. part. adj. acetoxidans acetate-oxidizing).

Cells are oval to rod-shaped, $1.3 \times 1.9-2.2 \mu \mathrm{m}$, singly or in pairs. Cells do not form spores and are Gramnegative. Acetate is the only electron donor and carbon source used. Sulfate, sulfite and thiosulfate can serve as electron acceptors. The optimum $\mathrm{pH}$ is $7 \cdot 7-7 \cdot 5$, the optimum temperature is $37^{\circ} \mathrm{C}$. Growth is optimal in freshwater medium. The $\mathrm{G}+\mathrm{C}$ content of the DNA is $51 \cdot 1 \pm 0 \cdot 2 \mathrm{~mol} \%$. Habitat is granular sludge from an upflow anaerobic sludge bed (UASB) reactor fed with acetate and sulfate. The type strain is $\operatorname{ASRB}^{\mathrm{T}}{ }_{(=}$ DSM $11109^{\mathrm{T}}$ ).

\section{ACKNOWLEDGEMENTS}

We thank A. Visser for supplying the granular sludge and for his useful information about the laboratory-scale reactor. We are indebted to A. Atteia for her help with the cytochrome characterization and to A. Wolterink for his help with the construction of the phylogenetic tree. We also like to thank W. M de Vos and A. D. L. Akkermans for their stimulating discussions. This work was supported financially by a grant from Senter-IOP milieubiotechnologie (IOP 90209), and from the European Communities (EC-HRAMI project BIO2-CT94-3098) and by Paques BV, Balk, The Netherlands.

\section{REFERENCES}

Alphenaar, P. A., Visser, A. \& Lettinga, G. (1993). The effect of liquid upward velocity and hydraulic retention time on granulation in UASB reactors treating wastewater with a high sulphate content. Biores Technol 43, 249-258.

Bradford, M. M. (1976). A rapid and sensitive method for the quantitation of microgram quantities of protein utilizing the principle of protein-dye binding. Anal Biochem 72, 248-254.

Colleran, E., Finnegan, S. \& Lens, P. (1995). Anaerobic treatment of sulphate-containing waste streams. Antonie Leeuwenhoek 67, 29-46.

Doetsch, R. N. (1981). Determinative methods of light microscopy. In Manual of Methods for General Bacteriology, pp. 21-33. Edited by P. Gerhardt, R. G. E. Murray, R. N. Costilow, E. W. Nester, W. A. Wood, N. R. Krieg \& G. B. Phillips. Washington, DC: American Society for Microbiology.

Gujer, W. \& Zehnder, A. J. B. (1983). Conversion processes in anaerobic digestion. Water Sci Technol 15, 127-167.

Harada, H., Uemura, S. \& Momonoi, K. (1994). Interaction between sulfate-reducing and methane-producing bacteria in UASB reactors fed with low strength wastes containing different levels of sulfate. Water Res 28, 355-367.

Harmsen, H. J. M., Wullings, B., Akkermans, A. D. L., Ludwig, W.
\& Stams, A. J. M. (1993). Phylogenetic analysis of Syntrophobacter wolinii reveals a relationship with sulfate-reducing bacteria. Arch Microbiol 160, 238-240.

Hungate, R. E. (1969). A roll tube method for cultivation of strict anaerobes. Methods Microbiol 3b, 117-132.

Isa, Z., Grusenmeyer, S. \& Verstraete, W. (1986). Sulfate reduction relative to methane production in high-rate anaerobic digestion: technical aspects. Appl Environ Microbiol 51, 572-579.

Jetten, M. S. M., Stams, A. J. M. \& Zehnder, A. J. B. (1990). Acetate threshold values and acetate activating enzymes in methanogenic bacteria. FEMS Microbiol Ecol 73, 339-344.

Jetten, M. S. M., Stams, A. J. M. \& Zehnder, A. J. B. (1992). Methanogenesis from acetate: a comparison of the acetate metabolism in Methanothrix soehngenii and Methanosarcina sp. FEMS Microbiol Rev 88, 181-198.

Ludwig, W. \& Strunk, O. (1996). ARB, a Software Environment for Sequence Data: a Preliminary Manual. Dept of Microbiology, Technical University of Munich, Germany.

McCartney, D. M. \& Oleszkiewicz, J. A. (1991). Sulfide inhibition of anaerobic degradation of lactate and acetate. Water Res $\mathbf{2 5}$, 203-209.

Mahler, H. R. \& Cordes, E. H. (1969). Biological Chemistry, 5th edn. New York: Harper \& Row.

Oude Elferink, S. J. W. H., Visser, A., Hulshoff Pol, L. W. \& Stams, A. J. M. (1994). Sulfate reduction in methanogenic bioreactors. FEMS Microbiol Rev 15, 119-136.

Oude Elferink, S. J. W. H., Maas, R. N., Harmsen, H. J. M. \& Stams, A. J. M. (1995). Desulforhabdus amnigenus gen. nov. sp. nov., a sulfate reducer isolated from anaerobic granular sludge. Arch Microbiol 164, 119-124.

Postgate, J. R. (1959). A diagnostic reaction of Desulphovibrio desulphuricans. Nature 183, 481-482.

Rees, G. N., Grassia, G. S., Sheehy, A. J., Dwivedi, P. P. \& Patel, B. K. C. (1995). Desulfacinum infernum gen. nov., sp. nov., a thermophilic sulfate-reducing bacterium from a petroleum reservoir. Int J Syst Bacteriol 45, 85-89.

Schauder, R., Eikmanns, B., Thauer, R. K., Widdel, F. \& Fuchs, G. (1986). Acetate oxidation to $\mathrm{CO}_{2}$ in anaerobic bacteria via a novel pathway not involving reactions of the citric acid cycle. Arch Microbiol 145, 162-172.

Smith, P. H. \& Mah, R. A. (1966). Kinetics of acetate metabolism during sludge digestion. Appl Microbiol 14, 368-371.

Thomas, P. E., Ryan, D. \& Levin, W. (1976). An improved staining procedure for the detection of the peroxidase activity of the cytochrome $\mathrm{P} 450$ on sodium dodecyl sulfate polyacrylamide gel. Anal Biochem 75, 168-176.

Trüper, H. G. \& Schlegel, H. G. (1964). Sulphur metabolism in Thiorhodaceae. 1. Quantitative measurements on growing cells of Chromatium okenii. Antonie Leeuwenhoek 30, 225-238.

Visser, A. (1995). The anaerobic treatment of sulfate containing wastewater. PhD thesis, Wageningen Agricultural University.

Visser, A., Beeksma, I., van der Zee, F., Stams, A. J. M. \& Lettinga, G. (1993a). Anaerobic degradation of volatile fatty acids at different sulphate concentrations. Appl Microbiol Biotechnol 40, 549- -556

Visser, A., Alphenaar, P. A., Gao, Y., van Rossem, G. \& Lettinga, G. (1993b). Granulation and immobilisation of methanogenic and sulfate reducing bacteria in high rate anaerobic reactors. Appl Microbiol Biotechnol 40, 575-581.

Wallrabenstein, C., Gorny, N., Springer, N., Ludwig, W. \& Schink, B. (1995). Pure culture of Syntrophus buswellii, definition of its 
phylogenetic status, and description of Syntrophus gentianae sp. nov. Syst Appl Microbiol 18, 62-66.

Whitman, W. B., Bowen, T. L. \& Boone, D. R. (1992). The methanogenic bacteria. In The Prokaryotes, 2nd edn, pp. 719-767. Edited by A. Balows, H. G. Trüper, M. Dworkin, W. Harder \& K.-H. Schleifer. New York: Springer.

Widdel, F. (1987). New types of acetate-oxidizing, sulfatereducing Desulfobacter sp., D. hydrogenophilus sp. nov., D. latus sp. nov., and D. curvatus sp. nov. Arch Microbiol 148, 286-291. Widdel, F. (1992). The genus Desulfotomaculum. In The Pro- karyotes, 2nd edn, pp. 1792-1799. Edited by A. Balows, H. G. Trüper, M. Dworkin, W. Harder \& K.-H. Schleifer. New York: Springer.

Widdel, F. \& Bak, F. (1992). Gram-negative mesophilic sulfatereducing bacteria. In The Prokaryotes, 2nd edn, pp. 3352-3378. Edited by A. Balows, H. G. Trüper, M. Dworkin, W. Harder \& K.-H. Schleifer. New York: Springer.

Widdel, F. \& Pfennig, N. (1981). Sporulation and further nutritional characteristics of Desulfotomaculum acetoxidans. Arch Microbiol 159, 282-288. 